\title{
Introduction. Modernist Revolutions: American Poetry and the Paradigm of the New
}

\section{Clément Oudart}

\section{(2) OpenEdition \\ Journals}

Electronic version

URL: https://journals.openedition.org/transatlantica/8187

DOI: $10.4000 /$ transatlantica.8187

ISSN: 1765-2766

\section{Publisher}

Association française d'Etudes Américaines (AFEA)

Electronic reference

Clément Oudart, "Introduction. Modernist Revolutions: American Poetry and the Paradigm of the New ", Transatlantica [Online], 1 | 2016, Online since 18 February 2017, connection on 31 January 2023. URL: http://journals.openedition.org/transatlantica/8187 ; DOI: https://doi.org/10.4000/transatlantica. 8187

This text was automatically generated on 31 January 2023.

\section{(†)

Creative Commons - Attribution-NonCommercial-NoDerivatives 4.0 International - CC BY-NC-ND 4.0 https://creativecommons.org/licenses/by-nc-nd/4.0/ 


\title{
Introduction. Modernist Revolutions: American Poetry and the Paradigm of the New
}

\author{
Clément Oudart
}

'Literature is news that STAYS news' Ezra Pound, $A B C$ of Reading, 1934

1 By bringing together such critical touchstones as Modernism, Revolution(s), and the New, this issue seeks to draw attention to one of the foundational mirages of the modernist experience, that of a clear-cut, definitive, history-bound Modernist revolution. Rather than engage in yet another attempt to pin down an ultimate definition or to settle the debate regarding the blurry timeframe of early, high, late (let alone post-) Modernism, the purpose of this issue is to revisit the modernists' revolutionary claims and their vicissitudes through over a century of experimental writing. From the "cradle of modernism" (Rabaté, 2007)-with the 1913 New York Armory Show and the publication, arranged from London by Ezra Pound, of H.D.'s first Imagist poems in Chicago's Poetry magazine-to the latest writings of, say, Susan Howe, the writing of innovative verse has gone through a bewildering sequence of movements, breaks, manifestoes and revolutions. To such an extent that one may wonder if the word revolution should not be understood literally and in the plural, as pointing less to the coming of age of a Marxian upheaval than to the planetary revolutions of a global poetic trend whose inherent obliquity prevents the perpetual return of the same and the paradoxical establishment of an ongoing "tradition of the new" (Rosenberg, 1959). Such debate about drastic change is unavoidably haunted by Eugene Jolas and his "Revolution of the Word" transition issue of 1929. His much-quoted "Proclamation" fostered the literary craftsman's use of a dismantled syntax, along with the disintegration of pre-existing words and fashioning of a new, multilingual idiom, understood as the literary means for an intercontinental revolution. Reading modernism requires tackling the double bind of innovative writing: the resurgence of revolutionary claims and the new forms of the "New" in American poetry-both in the 
critical and creative arenas-from the early twentieth to the early twenty-first centuries.

\section{Pound's Renovation or Make It New's Old News}

2 A key axiom of the modernist rhetoric of rupture seems to be predicated upon a multifaceted paradox, which in itself aptly encapsulates the tensions and contradictions underlying the modernist endeavor. The famous Poundian expression, an apparent injunction, is mostly remembered as a revolutionary call-to-arms (make it new!), or as the very definition of the task of the true poet (to make it new). Although the phrase is usually associated with the inaugural modernist moment, it mostly gained circulation owing to its visibility as the largely allusive and mostly misunderstood title of Pound's collection of essays, published in London in 1934 and in the U.S. the following year. Yet the publication date signals that it had little to do with the incipient modernist breakthrough, or with any revolutionary call to action complete with an exclamation mark, as a misperception long maintained the idea. True, the book gathered essays written between 1908 and 1920, but as such came across as rather old news at the time of publication. Oddly enough, Make It New's timing turns out to be rather off, both "too late" and "too early," to paraphrase Guy Davenport, ${ }^{1}$ and either way the contents proved no match to what appeared-and indeed was chiefly mistaken -to be the claim on the wrapping.

Ezra Pound, Make It New, New Haven (CT), Yale UP, 1935

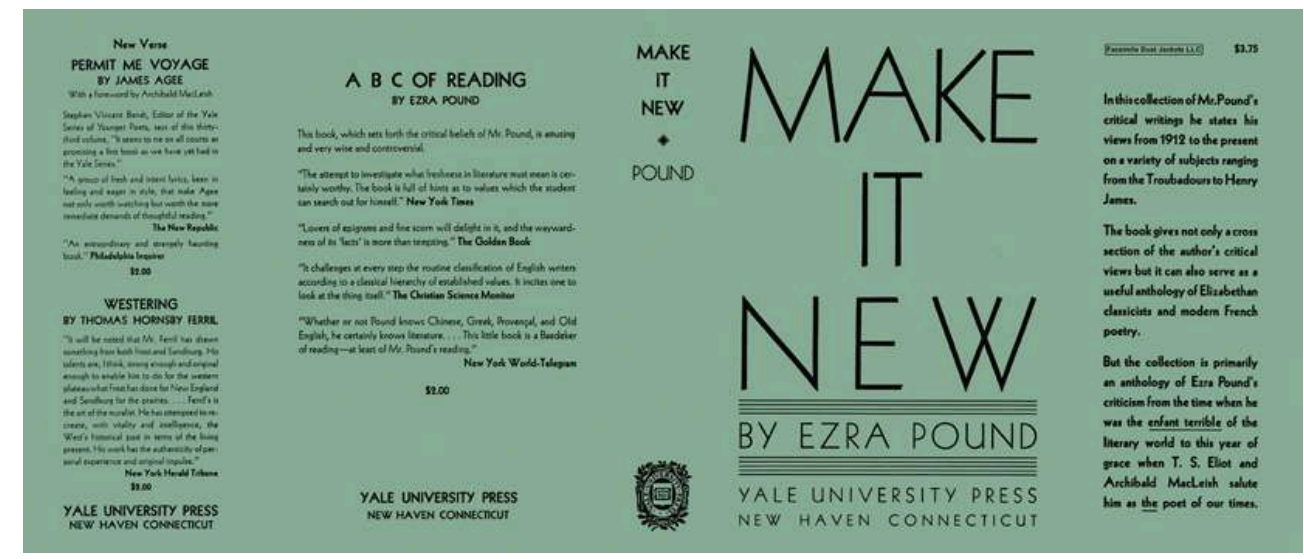

(c) Yale University Press

Under the banner of radical change, Pound mixes old and new critical material of his, from the oldest, "Date Line," which he had written in Rapallo in 1912 and where he wryly confessed that "[i]t is impossible to deal with the whole question of education, 'culture,' paideuma, in one volume of literary criticism" (Make It New, 1934, 5), to various essays on the "Troubadours" (1913), "Arnaut Daniel" (1920), "Elizabethan Classicists" (1917-18), “Translators of Greek” (1918-19; 1920), "French Poets" (1918), "Cavalcanti” (1910/1931), Henry James (1918), Rémy de Gourmont (1920), and the much-quoted "A Stray Document," originally entitled "A Retrospect" when published in 1918, made up of notes on poetics from the period 1908-1912, compiled with "A Few Don'ts" from 1913 and further notes from 1917. Ironically, then, most of the material published under the arresting headline (Make It New) was fifteen to twenty years old and circulated in small 
journals when selected for a reprint. Besides, in most essays Pound's primary concern was to fashion a Western poetic canon in keeping with his increasingly reactionary values, to delineate a European, or rather a Romance tradition of master texts from the Medieval and Renaissance eras, rather than to expose his latest theory promoting a fresh -ism(e) (Symbolisme, Imagisme, Vorticism). Yet, as Michael North has forcefully argued in Novelty: A History of the New (2013), Pound's own recycling of old material was indeed in accordance with the actual meaning of the phrase, and its complex genealogy: "when Pound chooses Make It New as the title for his collection of essays on the troubadours, Elizabethan classicists, and translators of Greek, he is being consistent with the tradition of cultural rediscovery and rebirth exemplified by the Italian Renaissance" (North, "The Making of 'Make It New").

In Jefferson and/or Mussolini (1935), published the same year as the American edition of Make It New, Pound quotes the Ta Hio, one of the core books making up the doctrine of Confucianism, where the poet had found the original reference. In a passage entitled "King Tching T'ang on Government. Part of the inscription on the king's bath-tub cited by Kung in the Ta Hio II. I.," Pound wrote: "One should respect intelligence, 'the luminous principle of reason,' the faculties of others, one should look to a constant renovation.//"Make it new, make it new as the young grass shoot"' (28). The Confucian philosophy and its faith in organic renewal (re-novation) is now warped by Pound's reading ancient wisdom through a Fascist lens.

Title page of Make It New, London, Faber, 1934. @ Faber and Faber

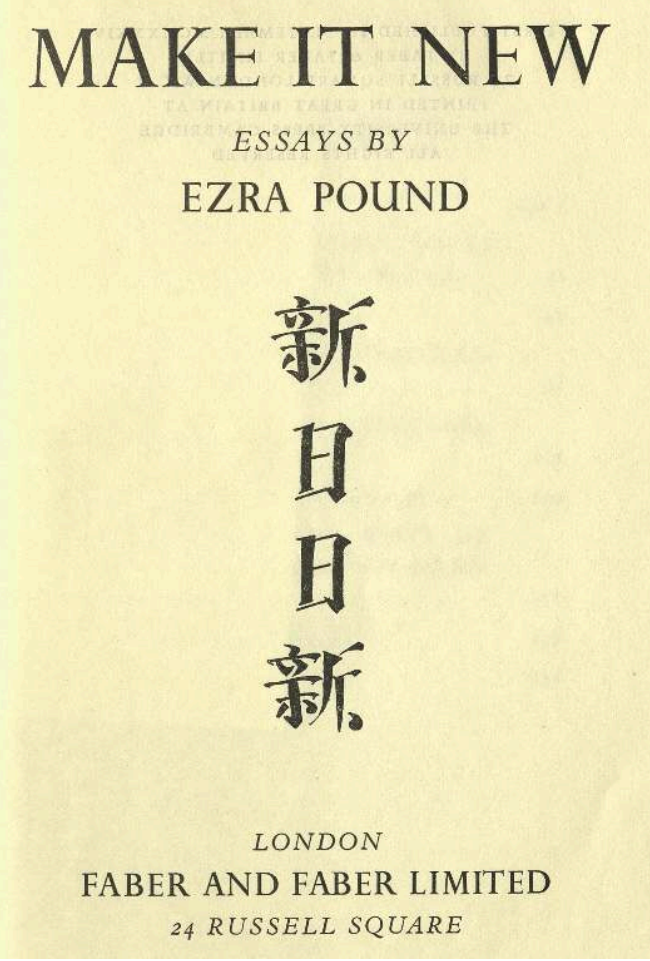

Image courtesy of the Poetry Collection of the University Libraries, University at Buffalo, The State University of New York

The two Chinese ideograms inscribed on the title page of Make It New, transcribed as hsin et jih following Fenollosa's system in The Cantos (265), designate on the one hand 
the process of destruction and purification, namely vegetal regeneration, and on the other the sun, day and renewal ("to put away old habits, the daily increase of plants, improve the state of, restore"): "The first ideogram (on the right) shows the fascist axe for the clearing away of rubbish (left half) the tree, organic vegetable renewal. The second ideograph is the sun sign, day, 'renovate, day by day renew"' (Jefferson and/or Mussolini, 20). Rather than innovation, Pound actually praises renovation. Rather than revolution, restoration. The language of Fascism and the rhetoric of reaction henceforth recover the original Confucian thought.

6 It wasn't until the publication of his Cantos LII-LXI (1940), a cycle known as the Chinese History Cantos that Ezra Pound acknowledged the source of his catchphrase more specifically when chronicling the life of China's great emperors:

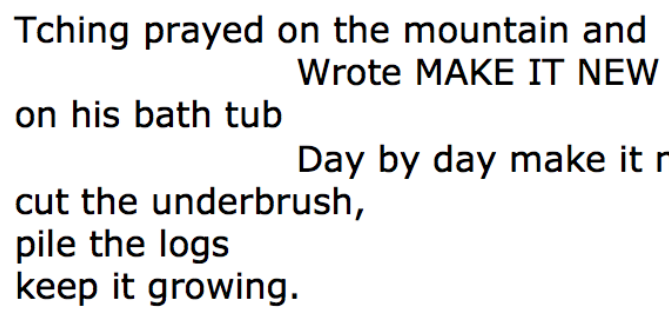

7 Canto LIII opens with the "First Dinasty hia" before moving on to "Tching Tang of Chang" (1766-53 BC), who, according to Confucius, had inscribed the motto on his washbasin or bathtub. Pound knew the Ta Hio by Confucius through Victorian sinologist James Legge, who translated the phrase as "If you can one day renovate yourself, do so from day to day. Yea, let there be daily renovation." Pound was implementing what he exhorted his readers to do: "cut the underbrush, / pile the logs / keep it growing" are in Pound's mind the ideogrammic components assembled in the character xin or hsin 新 (“new”): an axe 斤, logs 木, and growth 立. Through his practice of ideogrammic distortion or mistranslation, Pound not only altered Legge's original English translation, he also made up a new understanding of the Chinese language and created a new method for composing poetry. As Michael North explains, Pound started providing a scrupulously warped vision of the Confucian tenet to adapt it artificially to the modern Mussolinian travesty of "continuous revolution":

It was Pound's own inventiveness that associated the ancient Chinese hatchet with the Fascist axe and his own increasingly vindictive hatred of complications that provided the rubbish, which is not present in the Chinese original. Pound had in fact taken his slogan quite a way from its Chinese origins, which emphasized the necessity of selfrenewal, not the forced renewal of others, and he had removed it even farther from any association with avant-garde agitation. (North, "The Making of 'Make It New"')

Interestingly, though, Pound also discovered the Ta Hio by way of the French translation he owned by M. G. Pauthier, Confucius et Mencius: Les quatre livres de philosophie morale et politique de la Chine (1858), and which translated the phrase as: "Renouvelle-toi complètement chaque jour; fais-le de nouveau, encore de nouveau, et toujours de nouveau." When Pound published his own translation of Confucius as Ta Hio: The Great Learning, Newly Rendered into the American Language (1928), he translated the motto from Pauthier's French as: "Renovate, dod gast you, renovate!" He therefore steered away from a more literal translation of Pauthier's French, but supplied a more straightforward translation in a footnote: "renew thyself daily, utterly, make it new and again new, make it new." It is in this footnote, then, that the phrase "make it new" 
appears for the first time. And it is rather fascinating that it should directly stem from a mistranslation of "fais-le de nouveau," which, if rendered correctly as "do it anew," would have dramatically changed the literary history of Modernism. Michael North comments on the influence of Pound's mistake on the history of modernism:

Moreover, "make it new" seems to remove the reflexive sense present in all these translations and thus to turn the aphorism away from its obvious topic of selfrenovation. But Pound is clearly a little transfixed by the italicized nouveau, attracted to it, and oblivious to the possibility that its force might not be augmented but rather diluted by repetition. (North, "The Making of 'Make It New"')

In short, what the text meant and what Pound should have translated was: Make Yourself New, Utterly, Every Day (do it anew, and anew, and anew). Of tremendous significance is the fact that Pound never used the phrase "make it new" without the two ideograms he associated with it (hsin and jih), whether on the title page of Make It New, in his translation of the Ta Hio, in Jefferson and/or Mussolini or in Canto LIII. The phrase was never used as a catchphrase removed from its Chinese context, wrenched from its ancient philosophical and linguistic roots, which definitely gave his concept of novelty its fullness of meaning. Of course, and quite fittingly somehow, the critical fortune enjoyed by the phrase from the 1950s onward added layers of distortion and recycling to this very old idea of the new.

\section{新日日新: “make it noo"?}

10 All in all, "make it new" is a key phrase that is useful to understand Modernism, but for other reasons than usually expected. To sum up Michael North's line of thought, it is interesting because it wasn't Pound's-or new-at all, but was most ancient, and utterly unoriginal, ${ }^{2}$ since the idea first appeared in a Confucian text; because it had initially nothing to do with art but consisted in encouraging political rulers to keep their principles fresh; because it involved self-renewal and was no injunction or exhortation, certainly not to urge others to produce original art; because the phrase derives from a misreading, from a willful mistranslation of a (French) translation of the original Chinese characters; because it also has an eerie antecedent in the Biblical language of the New Testament, especially Revelation 21:5, which promises, "Behold, I make all things new." The reception and growing circulation of the phrase in critical discourse is also noteworthy. First, when Pound suggested the phrase for the title of his essay collection, T.S. Eliot warned Pound that Faber was not "altogether happy about [his] new title make it noo [sic] we may have missed subtle literary allusion but if we do I reckon genl public will also" (quoted in North, "The Making of 'Make It New"). Eliot's own reaction, pleading ignorance in the face of the obscure new title, is revelatory of the fact that even one of Pound's closest readers and supporters (Faber also published Pound's ABC of Reading in 1934 and Eliot later edited his Literary Essays) could not make sense of the phrase and, perhaps more importantly, refused to take its meaning for granted, as most subsequent readers unfortunately would. Not only was the phrase a solipsistic reference, an unacknowledged borrowing, and yet another idiosyncrasy in the Poundian vocabulary of the 1930s, but it remained so until the 1960 s, after the distorted Confucian fragment gained exposure in the critical lexicon of Hugh Kenner, as the latter lifted it directly from Pound's translation of the Ta Hio, now called the Great Digest, which he reviewed in 1950. From that point on, as it proceeded with its 
critical journey from Northrop Frye to Roy Harvey Pearce and many others, the phrase started being gradually disconnected from its Confucian background and consequently increasingly mistaken for Pound's own injunction to be inventive back in the 1910s. Michael North analyzes the fluctuating value of the modernist slogan:

In the course of this remarkably brief transformation, Pound's three-word phrase loses its ancient Chinese context, its debt to the devotional program of Legge, and its involvement in Mussolini's Fascism. The bibliographical facts of its appearance in Pound's work are so thoroughly obscured that it becomes possible for scholars such as Peter Gay and Alfred Appel to misplace it to 1914, where it can seem influential and even foundational instead of obscure. In the process, the role of novelty in the development of aesthetic modernism is distorted, and the nature of novelty itself is simplified. The vast array of different positions that can be identified among the practitioners of modern art and literature shrinks to the size of a simple, three-word slogan, and the complex history of novelty is subtracted even from that, so that modernism loses a crucial part of the debt to tradition that it owes, paradoxically, through its devotion to the new. (North, "The Making of 'Make It New")

Very much in line with Michael North's enlightening use of context and painstaking analysis of vocabulary, the articles gathered in this issue all seek to avoid oversimplified statements about the New, the experimental tradition in modernist poetry and the revolutionary rhetoric of the avant-garde. They all share a common concern, which consists in enquiring into the complex history of "Modernisms" (to echo the title of Peter Nicholls' seminal book) with regard to adding nuance and new forceful arguments in their personal reading of modernist works and/or their critical reception.

\section{The New "New": Restoration v. Revolution}

The history of novelty in twentieth century poetics is suffused with various tensions stemming from competing forms of discourse, especially rivaling uses of key words such as "modernism" or "new." The conflict between the two main sides of the poetic field was suitably summed up by David Antin in his influential essay "Modernism and Postmodernism: Approaching the Present in American Poetry" published in the inaugural issue of boundary 2: a journal of postmodern literature in 1972. In this essay, Antin argued that the work of the modernists had largely been stifled by the ingrained antimodernism of the New Critics (C. Brooks, R. Penn Warren, I. A. Richards), whom he then dubbed the champions of "the Metaphysical Modernist tradition" (120). For Antin, there were indeed two (poetic and critical) traditions trying to pass for Modernism: the official, institutionalized, Southern Agrarian tradition (Later Eliot, Auden, Ransom, Tate, then Lowell, Jarrell, Schwartz, Snodgrass), as opposed to the other tradition, which claimed Pound, Early Eliot, Williams, H.D., Stein, and later Zukofsky, Oppen, Rexroth, Ginsberg, Olson, Duncan, Creeley, etc. David Antin's stance would later be taken up by Pierre Joris and Jerome Rothenberg in their luminous introduction to the first volume of the behemoth anthology Poems for the Millennium: The University of California Book of Modern and Postmodern Poetry:

With regard to twentieth-century poetry, a new look has long been overdue. In the American instance, views of "modern poetry" established at midcentury have largely continued to the present and, as they entered the standard anthologies and literary 
histories, have tended to play down the more revolutionary aspects of modernism in favor of the recognition of a handful of "major" figures, many of whom are celebrated precisely for their antiexperimental and antirevolutionary positions or for their adherence to a relatively conventional view of poetic traditions and formal possibilities. $(1995,11)$

Their analysis would be made even clearer in the preface to the second volume of Poems for the Millennium:

In the United States, where experimental modernism had yet to make its ineluctable breakthroughs, the first postwar decade was marked by an ascendant literary "modernism"-hostile to experiment and reduced in consequence to a vapid, often stuffy middle-ground approximation. It was in that sense the Age of Eliot and the new critics, as they were then called-not as an extension of Eliot's collage-work in The Waste Land, say, but as a dominant and retrograde poetics in which the old ways of the English "great tradition" were trotted out and given privilege. $(1998,3)$

Yet, with hindsight, Antin was also taking his cue from Robert Duncan, who had largely mapped the tension-fraught poetic field in various essays, namely those collected posthumously in The H.D. Book (2012). In an unpublished essay fragment tracing "The Influence of Ezra Pound's Cantos" written while he was briefly teaching at Black Mountain College in 1956, Duncan wrote:

In the 30s a critical reaction took many paths. But in large the influence of Auden [...], of Rilke and Lorca (toward passionate fantasy), of the English (Empson) and the Southern Regionalists (Eberhart, Ransom, Tate, Laura Riding) toward metaphysical conceit meant even an hostility toward metrical invention and complexity, and an open disregard for objectification. In the present usage [1956], the poetics of The Cantos has few adherents. Certainly the dominant aesthetic is that of the critical reaction: Shapiro, Wilbur, Horan, Bishop, Roethke, Bogan, Garrigue, Lowell (who does however have strength in his measure) all exhibit disinterest and even ignorance of form and invention. Hence recourse to convenient traditions. ${ }^{3}$ Duncan indeed engaged with the "poetics and polemics" (Rothenberg, 2008) of his generation, having not only to deal with the difficult Modernist legacy of barely legible works but also to deconstruct the claims of the poets and/or their powerful devotees within the literary institution. The poet was quick to identify the inner contradiction underlying the whole modernist aesthetic: "They were-Pound or H.D. or Joyce-most modern in their appropriation of the past" (The H.D. Book, 229). Reflecting on the paradoxical nature of modernism's modernity, Jean-Michel Rabaté has notoriously argued that the Anglo-American modernists were concerned with primitivism in ways unequaled by the European avant-gardes: "the modernity of high modernism lies above all in its main proponents' heightened awareness of the primitive nature of ritual ... Their 'modernity' remains caught in the dialectics of the avant-garde, with its load of culturalist, pedagogical and exhibitionistic impulses attempting to make up for its failure to think the archaic" (1993, 199-200, my translation). In other words, modernism's modernity lies in its staunch archaism and fascination for primitivism. ${ }^{4}$ Here is Rothenberg and Joris's excellent synthesis on this point:

Thus, if an awareness of the "new," say, seems central to these projects, it is often balanced, sometimes overbalanced, by an obsession with old and the ancient. This represents a problematic and an issue, as do polarities of high and low (in language, in diction), of symbolism and realism, lyric exuberance and "objective" precision, 
hermetic condensations and epic expansions, minimals and maximals, verses and proses, sacred and secular, maleness and femaleness. While the predilections of the work is to push things to their limits, even those limits (and that predilection) may be called into question-as in the Dada poet's turning on the Dada work: "The true Dadas are against Dada." Or put another way: at the core of every true "modernism" is the germ of a postmodernism. $(1995,3)$

Much less consensual was Marjorie Perloff's introduction to 21st-Century Modernism: The "New" Poetics (2002). Published in the Blackwell Manifesto series, the controversial essay incurred a critical storm within the wider field of experimental poetry, with reactions in notable review-essays by Jennifer Ashton and Stephen Fredman, among countless others. ${ }^{5}$ Among the reasons for the fiery debate surrounding Perloff's polemical statement was the author's choice of polarizing vocabulary, essentially drawing on the revolution-restoration opposition. Let us take two examples, among the many bold and thought-provoking claims. The first deals with Donald Allen's The New American Poetry: 1945-1960 (1960, reed. 1999), and more specifically literary history's treatment of the Black Mountain poets and the Beat movement:

Allen's anthology introduced the literary public to some of the most exciting poets coming of age in the late fifties: Frank O'Hara and John Ashbery, Robert Creeley and Robert Duncan, Allen Ginsberg, Amiri Baraka (then LeRoy Jones) and Jack Spicer. Compared to the "closed verse" poets featured in the rival anthology, Donald Hall's New Poets of England and America (1957), the "New Americans" were indeed a breath of fresh air. But from the hindsight of the twenty-first century, their fabled "opening of the field" was less revolution than restoration: a carrying-on, in somewhat diluted form, of the avant-garde project that had been at the very heart of early modernism. (Perloff, 2002, 2)

With its judgmental ring and devaluing innuendo, the binary revolution-restoration is intentionally antagonizing. Perloff deliberately reproduces the rhetoric of rupture ${ }^{6}$ which had been so efficiently foregrounded by the avant-gardes themselves, starting with the Futurists, the Vorticists and Dada. Here came the main thrust of the argument, aimed at downplaying the significance of the role and/or value of the "New American Poets," and strengthening as a result the Language Poets' aptitude for radical change and true innovation:

[W] hat strikes us when we reread the poetries of the early century, is that the real fate of first-stage modernism was one of deferral, its radical and Utopian aspirations being cut off by the catastrophe, first of the Great War, and then of the series of crises produced by the two great totalitarianisms that dominated the first half of the century and culminated in World War II and the subsequent Cold War. (Perloff, 2002, 2-3) In an earlier and yet equally seminal article entitled "Pound/Stevens: Whose Era?" (1982), Perloff argued: "Modernism, in this context, means rupture-not, of course, with the distant past which must be reassimilated, but with all that has become established and conventional in the art of one's own time" $(1985,14)$.

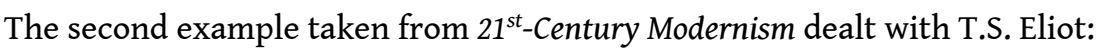

I am merely suggesting that between Eliot's radical poetry of the avant guerre and its postwar reincarnation, a decisive change had taken place. The Waste Land, in this scheme of things, emerges as the brilliant culmination of the poetic revolution that 
began with "Prufrock" in 1911 rather than as itself a revolutionary breakthrough or rupture. (Perloff, 2002, 39)

Although a number of critics voiced their disagreement with Perloff's use of polarization and sometimes scathing rhetoric, needless to say, the author's goal was brilliantly achieved. It reignited a much-needed debate about the "fate of modernism" (Nicholls), and for all its idealizing of the moment of "revolutionary breakthrough or rupture," it also raised the pivotal question of the ongoing Modernist impulse across the twentieth-century and into the twenty-first. About the continuity of a radical movement running through the past century, Hélène Aji further argued in "Ezra Pound and William Carlos Williams's Romantic Dilemmas: From Obliteration to Remanence":

One would however be tempted to expand Perloff's outlook and question the idea of a wholly new era to begin in the 1910s, especially as one tries to read through the layers of the Modernist intertext to its poetic claims of didacticism, commitment and intellectual leadership. Conceiving of innovation only in terms of rupture tends naively to endorse the poets' claims and their sometimes-willful concealments (...). (Aji, 2005, 50)

While it seems clear that the revolutionary assertions of the early modernist avantgarde had indeed been cautiously staged by the authors and overemphasized by a number of critics taking the poets' statements at face value, a reappraisal of the ongoing verve of the modernist impulse across over a century of writing seemed rather timely. ${ }^{7}$ As the articles in this special issue testify, modernist poetry projected itself as an instrument of change. The renewal of poetic language now calls anew for rewriting the history of modernism through its relation with novelty.

The first three articles are primarily focused on the first wave of modernism, thus from the 1910 s through the 1930s. "(Women Writing) The Modernist Line," penned by Cristanne Miller, opens the field of investigation with a reassessment of the modernist canon through a study of a range of key female protagonists: Mina Loy, H.D., Gertrude Stein, and Marianne Moore. How these writers experimented with the line-understood both as poetic lineage and semiotic unit-is key to this essay that invites readers to venture into the feminine margins of modernism so as to fully apprehend radical experimentation with formal invention. Aurore Clavier's piece entitled "'Radical': Marianne Moore and the Revision of Modernism" offers an excellent sequel to the opening article, as it provides ample historical contextualization before zooming in on Marianne Moore's poetry through the lens of her practice of textual emendation (erasure, crossing out, compression, correction), a poetic practice which is at the core of modernist poetics and yet whose ambivalent scope and significance is fully reappraised. Ezra Pound's drastic editing of T.S. Eliot's The Waste Land provides a link to the following article, authored by Viorica Patea, whose goal is to cast a fresh glance at "Eliot's Modernist Manifesto," his classic of modernist theory entitled "Tradition and the Individual Talent" (1919). The full controversial potency of the text is made clear through a study of its reception across a century. The opening sentence "In English writing we seldom speak of tradition" now sounds almost ironic in light of the critical output elicited by Eliot's groundbreaking outlook. Yet Eliot's unprecedented approach of the contemporary poet's relation to the Western canon was also a catalyst for his inner contradictions as the tension between his theory of impersonality and his use of avant-garde rhetoric receives more critical attention. 

poetic language of the Objectivist legacy. In "Beyond the American Difficult Poem: Paul Celan's 'Du liegst,"' Xavier Kalck adopts a comparative approach to inquire into the mechanics of one of modernism's defining features, its difficulty. By taking the reader through the experience of a German text and its subsequent translations into English, not to mention Celan's crucial influence on philosophy and theory, the author's intent is to examine what truly makes up our literary knowledge beyond the stakes of radicalism and the claims of innovation. Also concerned with a poetics of translation, Abigail Lang tackles American poetry from a foreign vantage point, that of "The Ongoing French Reception of the Objectivists," thereby closely reexamining over forty years' worth of transatlantic literary history through the "complex dynamics of textual circulation, reception and canonization," namely of Zukofsky and Reznikoff's influence on French experimental poets. Purposefully located at the boundary of creative and critical writing, Elizabeth Willis's contribution is entitled "The Open Boat and the Shipwreck of the Singular: American Poetry and the Democratic Ideal." As a poet herself, Willis addresses a core contradiction within American poetry's countertradition: "How is it that vanguard works of poetry and prose repeatedly re-enact foundational narratives of Americanness?" Through such enquiry into the roots of American poetry, Walt Whitman, Gertrude Stein and George Oppen are given a fresh glance.

The last two contributors explore the contemporary poetic scene through two traditions that are usually opposed. Following the critical concept of sincerity from Romanticism through Objectivism and Language poetry, Nicholas Manning inquires into the premises of the revolutionary v. conservative opposition in "The Rhetoric of the Rearguard? Sincerity in Innovative American Poetics." The author raises the following fundamental question: "How did the criterion of poetic sincerity transform, in the space of a half-century, from a fundamental tenet of radical modernism to an incarnation of lyrical and expressive orthodoxy?" To conclude, Marjorie Perloff's "Spectral Telepathy: the Late Style of Susan Howe" examines the latest works of one of the major voices in contemporary poetry. The author delineates an evolution in Susan Howe's skillful blending of criticism and poetry from My Emily Dickinson (1985) and The Birth-mark (1993) through The Quarry and Tom Tit Tot, both published in 2015, and shows how her experimental take on American history allows her to "reanimate literary texts and make them new."

AJI, Hélène, “Ezra Pound and William Carlos Williams's Romantic Dilemmas: From Obliteration to Remanence," Cercles, no. 12, 2005, 50-63.

ALLEN, Donald, ed., The New American Poetry: 1945-1960, New York, Grove Press, 1960 (new ed. 1999).

ANTIN, David, "Modernism and Postmodernism: Approaching the Present in American Poetry," boundary 2: a journal of postmodern literature, no. 1, Fall 1972, 98-133.

ASHTON, Jennifer, “Modernism's ‘New' Literalism,” Modernism/Modernity, vol. 10, no. 2, 2003, 381-390.

DAVENPORT, Guy, "Postscript,” Twelve Stories, Washington, DC, Counterpoint, 1997, 233-239.

DAVIDSON, Michael, The San Francisco Renaissance: Poetics and Community at Mid-Century, Cambridge, CUP, 1989. 
DUNCAN, Robert, “The Influence of Ezra Pound's Cantos” (1956), notebook 19, Robert Duncan Collection, The Poetry Collection of the University Libraries, University at Buffalo, The State University of New York.

---, The H.D. Book, ed. Michael Boughn and Victor Coleman, Berkeley, CA, University of California Press, 2012.

FREDMAN, Stephen, “21st-Century Modernism: The 'New' Poetics (review essay),” Symploke, vol. 7 , no. $1,2005,340-342$.

FURLANI, André, “Postmodern and After: Guy Davenport," Contemporary Literature, vol. 43, no. 4, Winter 2002, 709-735.

---, Guy Davenport: Postmodern and After, Evanston, Northwestern University Press, 2007.

NICHOLLS, Peter, Modernisms: A Literary Guide. Berkeley: University of California Press, 1995.

---, George Oppen and the Fate of Modernism, Oxford, OUP, 2007.

NORTH, Michael, Novelty: A History of the New, Chicago, University of Chicago Press, 2013.

---, “The Making of 'Make It New,'” Guernica: a magazine of global arts and politics, $2013 \mathrm{https}$ // www.guernicamag.com/the-making-of-making-it-new/ (last accessed January 15, 2017).

OUDART, Clément, Les Métamorphoses du modernisme de H.D. à Robert Duncan : vers une poétique de la relation, Paris, Presses Sorbonne Nouvelle, 2010.

---, ed., "Tailor-Made Traditions: The Poetics of U.S. Experimental Verse from H.D. to Michael Heller," Caliban: French Journal of English Studies, 35, 2014 https://caliban.revues.org/215 (last accessed January 15, 2017).

PERLOFF, Marjorie, The Dance of the Intellect: Studies in the Poetry of the Pound Tradition, Cambridge, CUP, 1985.

---, The Futurist Moment: Avant-Garde, Avant Guerre, and the Language of Rupture (1986, rpt. 2003).

---, 21st-Century Modernism: The “New” Poetics, Malden, MA, Blackwell, 2002.

---, Unoriginal Genius: Poetry By Other Means in the New Century, Chicago, University of Chicago Press, 2010.

POUND, Ezra, Make It New, London, Faber \& Faber, 1934 (Yale UP, 1935).

---, Jefferson and/or Mussolini, London, Stanley Nott, 1935.

---, The Cantos of Ezra Pound, New York, New Directions, 1996.

RABATÉ, Jean-Michel, La Pénultième est morte. Spectrographies de la modernité, Seyssel, Champ Vallon, coll. "L'or d'Atalante," 1993.

---, 1913: The Cradle of Modernism, Oxford and Malden, MA, Blackwell, 2007.

ROSENBERG, Harold, The Tradition of the New, New York, Horizon Press, 1959.

ROTHENBERG, Jerome, Poetics \& Polemics, 1980-2005, ed. S. Clay, Tuscaloosa, AL, University of Alabama Press, 2008.

--- and Pierre JORIS, eds., Poems for the Millennium. The University of California Book of Modern \& Postmodern Poetry, 2 vols., Berkeley \& Los Angeles, University of California Press, 1995-1998. 


\section{NOTES}

1. Guy Davenport, "Postscript," Twelve Stories (1997), 236: “A witty Frenchman has said that I am a writer who disappears while arriving. I would like to misunderstand him that I come too late as a Modernist and too early for the dissonances that go by the name of Postmodernism" (quoted in Furlani, "Postmodern and After: Guy Davenport," Contemporary Literature, vol. 43, no. 4, 2002, 709).

2. Cf. Marjorie Perloff, Unoriginal Genius: Poetry By Other Means in the New Century (2010).

3. Robert Duncan, "The Influence of Ezra Pound's Cantos," notebook 19, Robert Duncan Collection, The Poetry Collection of the University Libraries, University at Buffalo, The State University of New York.

4. In The San Francisco Renaissance: Poetics and Community at Mid-Century (1989), Michael Davidson writes: "The postmodernism of the San Francisco Renaissance, ironically, is its primitivism" (32).

5. Cf. The feud was chronicled in my own Les Métamorphoses du modernisme de H.D. à Robert Duncan (2010).

6. See Perloff, The Futurist Moment: Avant-Garde, Avant Guerre, and the Language of Rupture (1986, reed. 2003).

7. Several of the articles gathered in this issue were originally written for the "Modernist Revolutions" international conference organized at the University of Toulouse in 2014. I wish to express heartfelt thanks to all contributors and sponsors, especially to Prof. Nathalie Cochoy for making this event possible. On a related topic, see Oudart (ed.), "Tailor-Made Traditions: The Poetics of U.S. Experimental Verse from H.D. to Michael Heller” (Caliban, 2014).

\section{AUTHOR \\ CLÉMENT OUDART}

Université Paris-Sorbonne 